\title{
Toothbrushing with vegetable oil: a clinical and laboratorial analysis
}

\section{Escovação dentária com óleo vegetal: análise clínica e laboratorial}

\author{
Alciara Alice de Almeida Aguiar* \\ Nemre Adas Saliba**
}

\begin{abstract}
The dentifrices currently available in the marketplace contain many anticariogenic substances, fluoride and abrasives aimed to better clean the dental surface, remove dental plaque, improve salivary flow and its buffer capacity and reduce colonies of bacteria such as S. mutans, the causative agent of dental caries. The objective of this study was to evaluate the possibility of adequately removing dental plaque using an experimental almond oil dentifrice (Titoil) with no abrasives or antiplaque agents. This study was carried out with 80 volunteers, all of them 18-year-old recruits from the military training school of Araçatuba - SP. Saliva sampling and dental plaque disclosing were undertaken both before and after 28 days of toothbrushing with a low abrasive dentifrice (Group 1: 40 volunteers) or with Titoil (Group 2: 40 volunteers). Statistical analysis of the results revealed that the experimental dentifrice (Titoil) did not interfere with salivary flow and reduced dental plaque more than the low abrasive dentifrice, improved the salivary buffer capacity and decreased salivary S. mutans (Caritest-SM) as much as regular dentifrices. It was concluded that if the dental industry replaces abrasive by vegetable oil in dentifrices, these will be more effective in maintaining oral health and will cause less dental abrasion.
\end{abstract}

DESCRIPTORS: Dentifrices; Dental polishing; Dental plaque; Toothbrushing; Streptococcus mutans.

RESUMO: Os dentifrícios atualmente encontrados no mercado contêm muitas substâncias anticariogênicas, flúor e abrasivos para higienizar melhor as superficies dentárias, remover a placa dentária, melhorar o fluxo salivar e a capacidade tampão e reduzir as colônias bacterianas, como de $S$. mutans, agente causador da cárie dentária. O objetivo deste estudo foi avaliar a possibilidade de remover placa adequadamente usando um dentifrício experimental, sem abrasivos nem agentes antiplaca, à base de óleo de amêndoas: Titoil. Foi realizado um estudo com 80 recrutas de 18 anos de idade do Tiro de Guerra de Araçatuba - SP. A coleta de amostras de saliva e a coloração da placa dentária foram realizadas ao início e ao final de 28 dias de escovação com um dentifrício de baixa abrasividade (Grupo 1: 40 voluntários) ou com Titoil (Grupo 2: 40 voluntários). Através de análises estatísticas, os resultados mostraram que o dentifrício experimental: não interfere no fluxo salivar; promove maior redução de placa dentária do que o dentifrício de baixa abrasividade; melhora a capacidade tampão e diminui o número de $S$. mutans salivares (kit Caritest-SM) tanto quanto o dentifrício regular. Concluiu-se que, se as indústrias de dentifrício substituíssem os abrasivos dos dentifrícios por óleo vegetal, estes seriam mais eficientes na manutenção da saúde bucal e provocariam menos abrasão.

DESCRITORES: Dentifrícios; Polimento dentário; Placa dentária; Escovação dentária; Streptococcus mutans.

\section{INTRODUCTION}

Microorganisms present in the oral cavity are a prerequisite for caries and are very relevant for periodontal disease. Currently, it can be said that the microorganism with greatest cariogenic potential in man is Streptococcus mutans ${ }^{14}$. It has the capacity to produce, from sucrose, an extracellular polymer of glucose base (dextran) that assists it in the adhesion and permanence on the dental enamel $^{20}$. A fatty diet disturbs this process of adhesion.
Studies on fatty foods determine that they have a potential benefit, preventing the formation of caries. They are able to form a protective barrier on the enamel or involve the carbohydrates of the $\operatorname{diet}^{18}$. The fat not only interferes with the process of adhesion of bacterial plaque to the dental enamel, but it also reduces the number of bacteria added to the enamel ${ }^{14}$.

In a recent study, it was proven that when pure almond oil was employed in toothbrushing

\footnotetext{
*PhD Student; **PhD, Chairman - Discipline of Preventive \& Social Dentistry, School of Dentistry of Araçatuba, São Paulo State University.
} 
there was a reduction in dental plaque compared with regular dentifrices (containing abrasives and antiplaque agents). This occurred even with no change in toothbrushing techniques ${ }^{2}$.

Toothbrush and dentifrice are the most useful and widespread resources in the practice of oral hygiene $^{11}$, and supervised toothbrushing optimizes the reduction of dental plaque and gum bleeding ${ }^{5}$. However, the dentifrices in Brazil contain many different abrasives aimed to better remove dental plaque and enable polishing ${ }^{4}$.

The composition of dentifrices includes detergents, flavoring, humectants, water, sweeteners, colorants, wetting agents, surface-active agents and abrasives ${ }^{10}$. These abrasives cause great concern due to the wearing of dental surfaces.

Various attempts have been made to control plaque with chemical substances such as chlorhexidine, essential oils, triclosan, heavy metals, oxygenating agents and sanguinarine. These substances are added to the dentifrice or used as mouthwashes before or after toothbrushing ${ }^{15}$.

The surface roughness of the dental enamel caused by toothbrushing with abrasive dentifrices is an important factor in oral health. It modifies the shape of the dental surface, facilitating the retention of bacterial plaque, which is a cause for dental caries and periodontal diseases ${ }^{8}$.

It is considered that there is an increasing necessity to obtain a substance that removes bacterial plaque without causing any other damage, such as an increase in surface roughness and, consequently, the process of dental abrasion ${ }^{3}$.

Literature regarding the use of oil in dental brushing is not abundant ${ }^{1}$. Therefore, it is desirable to offer a clear understanding on the subject, which will demonstrate removal of bacterial plaque (preventing caries and periodontal disease) without interfering with the salivary flow and buffer capacity (important in the process of dental demineralization), without unbalancing the oral microorganisms (enabling prolonged use) and without causing abrasion of hard tissues of the oral cavity.

This study aims at examining the efficiency of a vegetable oil in the prevention of caries when used in toothbrushing. A comparison will be made between an experimental dentifrice with almond oil (Titoil) and a low abrasive dentifrice (Tandy, Kolynos, Brazil) available in the Brazilian marketplace in order to determine the correlation between: the ability to reduce dental plaque, the interference in salivary flow and buffer capacity and the influence on the quantity of Streptococcus mutans (microorganisms / $\mathrm{ml}$ of saliva).

\section{MATERIAL AND METHODS}

This study was carried out by the Laboratory and Clinic of Dentistry, School of Dentistry of Araçatuba (São Paulo State University) - Brazil, to analyze: a) salivary flow rate; b) bacterial plaque; c) buffer capacity of the saliva; d) Streptococcus mutans (SM).

Eighty male volunteers, 18 years of age, conscripts in the Army Training School of Araçatuba, participated in the study (according to Resolution n. 196/96 of CNS - Brazil). Detailed letters on the study were given to the authorities and volunteers of the Army Training School (approved by Ethic Committee of this College). In order to be included in the study, volunteers could not wear orthodontic devices, prosthesis nor be taking any medication. Two groups of 40 individuals were formed randomly. During the 4 weeks of the study, Group 1 used a regularly available low abrasive dentifrice (Low abrasive) according to instructions of the manufacturer Kolynos. Group 2 used the experimental dentifrice with almond oil (Amygdalus communis, Linné-Rosácea, Laboratório Industrial Farmacêutico Lifar Ltda., PR, Brasil), which had no abrasives.

The volunteers received material for toothbrushing and a standard toothbrush (used in the abrasion tests: Equilabor, Equipamentos para laboratórios, Piracicaba, Brazil) to use during the period of the study. They followed normal hygiene habits and did not change those habits during the study, in order not to influence the results.

The examinations were carried out with the same schedule for each volunteer in the same location and with the same examiner at the beginning of the study and after 4 weeks. A monitor conducted the volunteers for collection of stimulated saliva. Afterwards, the salivary flow and disclosing of dental plaque were observed in a clinical environment for examination of the plaque index. The examiner was assisted with the recording of the name and group of each volunteer, date and quantity of dental plaque in files appropriate for the score of Turesky index. Later, the examiner observed the salivary buffer capacity and quantity of microorganisms / $\mathrm{ml}$ of $\mathrm{S}$. mutans (Caritest $\mathrm{SM}^{\circledR}$, Tecnew Comércio e Indústria Ltda., RJ, Brazil).

The examiner was unaware of the composition of the two groups of volunteers. Groups were 
assigned by the assistant and monitor, thereby characterizing a "blind-study" 19

This study was preceded by a pilot study of 7 days using 10 volunteers, students of Dentistry.

\section{Test for salivary flow rate}

Salivary flow was stimulated with gum for 1 minute, being that the volunteer swallowed the resulting saliva (this causes an initial stimulation and removal of residues). The volunteer then expelled the saliva for 5 minutes into a beaker and the volume of saliva was divided by the time ( $5 \mathrm{~min}$ ) of collection, thereby obtaining the salivary flow ( $\mathrm{ml} / \mathrm{min})$. The parameters for salivary secretion were classified by Ericsson, Brathal ${ }^{7}$ (1989) (a flow of more than $1 \mathrm{ml} / \mathrm{min}$ is optimum, between 0.7 and $1 \mathrm{ml} / \mathrm{min}$ is normal and less than $0.7 \mathrm{ml} / \mathrm{min}$ is poor).

\section{Tests for the salivary buffer capacity}

For the gauging of the salivary buffer capacity, the Ericsson technique was modified for the increase in proportion of saliva/acid and substitution of the paper strip by a digital $\mathrm{pH}$-meter (Tecnal, Piracicaba, Brazil). In the evaluation, $1 \mathrm{ml}$ of previously collected saliva was placed into a test tube with $3 \mathrm{ml}$ of $\mathrm{HCl}(5 \mathrm{mM})$. Values equal to or greater than 5.6 were classified as optimum, from 4.5 to 5.5 as normal and less than 4.5 as poor.

\section{Dental plaque}

The Turesky index was employed in this evaluation $^{16}$. Through this index, a score from zero to five was used for buccal and lingual surfaces of each tooth according to the following criteria: (0) no plaque; (1) separate or discontinuous bands of plaque at the cervical edge of the dental surface; (2) narrow and continuous bands of plaque up to $1 \mathrm{~mm}$ wide at the cervical edge of the dental surface; (3) bands of plaque wider than $1 \mathrm{~mm}$ and on less than $1 / 3$ of the surface; (4) plaque covering between $1 / 3$ and $2 / 3$ of the surface; (5) plaque covering $2 / 3$ or more of the surface.

After the examination, the monitor assisted the volunteers to remove completely the disclosing solution by brushing the teeth with prophylaxis paste. The monitor provided each volunteer with a soft-bristled toothbrush and the substances for brushing the teeth for the 28 days of the study.

\section{Microbiological tests for Streptococcus mutans}

The microbiological test (Caritest-SM Kit, Tecnew Comércio e Indústria Ltda, Brazil) is a biochemical and bacteriological (semi-quantitative) test for the detection and monitoring of MGS ( $\mathrm{mu}$ tans of group Streptococcus) in saliva.

For this test, $1.5 \mathrm{ml}$ of saliva was used from the sample collected previously for the salivary flow test (maintained at low temperature in a container with ice until immediately prior to use). The test was performed following the normal instructions of the Caritest Kit manufacturers, with a comparison of density growth of the bacterial colonies without the aid of a microscope. The density levels are shown in the table of results evaluation (provided in the Caritest-SM Kit). The density in the table reflects the level of Streptococcus mutans present in the mouth of the volunteer per unit of saliva (microorganisms $/ \mathrm{ml}$ ).

\section{RESULTS}

The Wilcoxon test was used to evaluate salivary flow. It showed no statistically significant differences between the dentifrices, demonstrating that the substance prepared with almond oil did not interfere with the salivary flow (Graph 1),

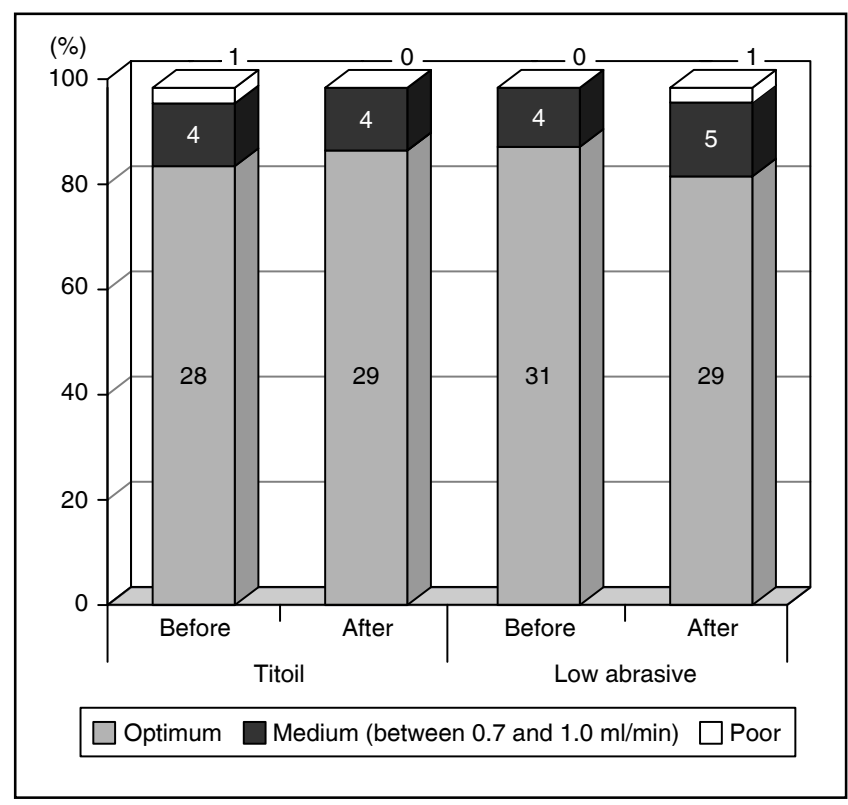

GRAPH 1 - Salivary flow of the two groups of volunteers, before and after 28 days of dental brushing with Titoil or a low abrasive dentifrice. 
which is important for the prevention of caries and oral health ${ }^{9}$.

A variance analysis was performed and Tukey's non-parametric test was applied at $5 \%$ and $1 \%$. It was shown that there was a significant reduction in dental plaque $(\mathrm{p}<0.01)$ after toothbrushing with Titoil and no reduction after toothbrushing with the low abrasive dentifrice (Graph 2). This

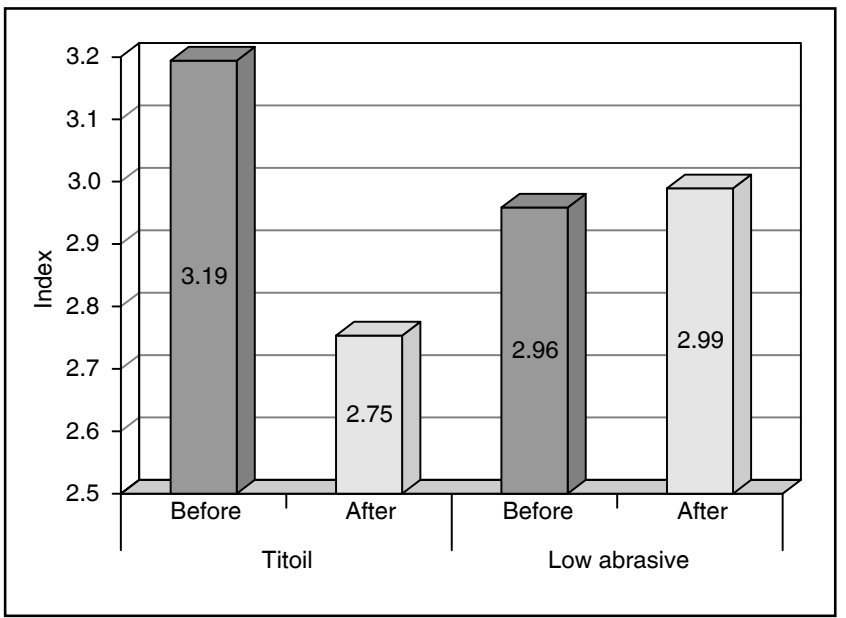

GRAPH 2 - Averages of the Turesky index for the two groups of volunteers, before and after 28 days of dental brushing with Titoil or a low abrasive dentifrice.

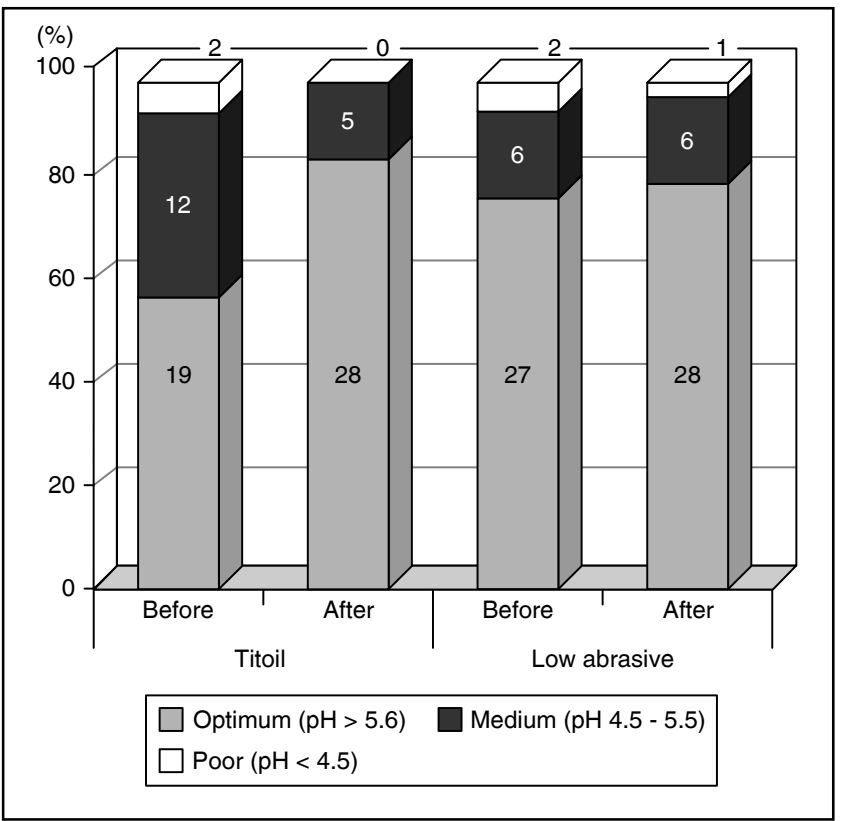

GRAPH 3 - Classification of the buffer capacity (Ericsson) of the two groups of volunteers, before and after 28 days of dental brushing with Titoil or a low abrasive dentifrice. proved that vegetable oil is effective in the reduction of dental plaque.

The variance analysis was applied and it was confirmed that there was no significant difference between the two tested substances in terms of salivary buffer capacity (Graph 3). This confirmed that Titoil does not interfere with the buffer capacity of saliva either, which is essential to avoid damages in oral tissues.

The variance analysis was performed and Tukey's test was applied to the microbiological test, which revealed a significant reduction $(\mathrm{p}<0.01)$ in the $\mathrm{CFU} / \mathrm{ml}$ of $S$. mutans after 28 days of toothbrushing (factor time) in both groups of volunteers. This demonstrates that even without chemicals, fluoride or abrasives, Titoil is very effective in reducing the quantity of bacteria compared with the low abrasive dentifrices (Graph 4) available in the Brazilian marketplace.

It was observed that the bacterial colonies also became smaller after 28 days of toothbrushing with Titoil (by stereoscopic microscopy) and therefore deserve further detailed in-depth studies.

Of the initial 80 volunteers, seven of Group 1 and five of Group 2 withdrew from the study. As a result, only 33 volunteers from Group 1 and 35

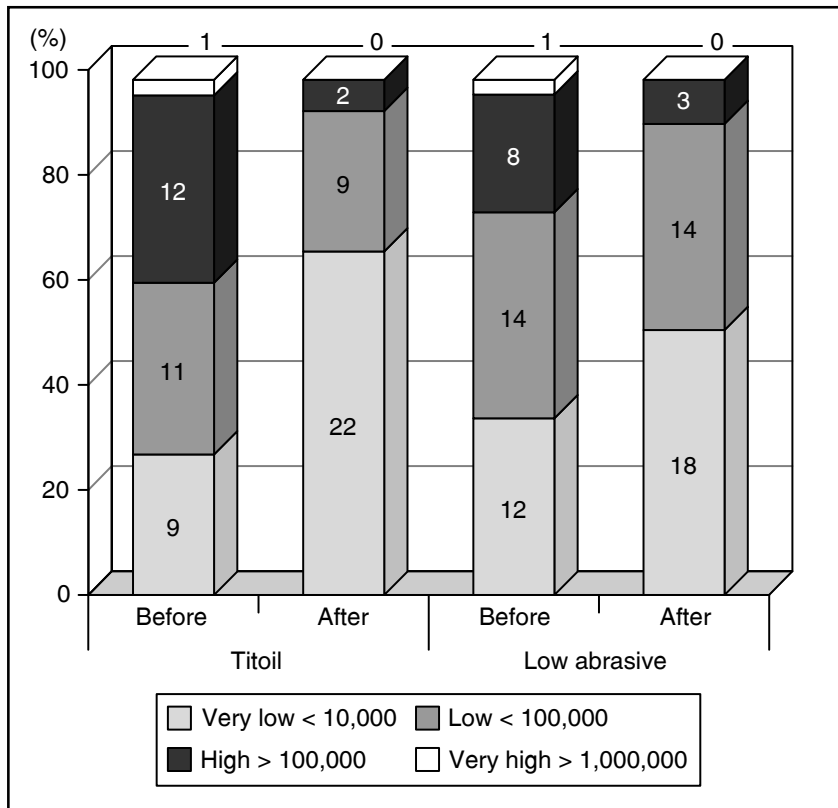

GRAPH 4 - Classification of the Caritest-SM for the risk of caries per microorganisms/ml of saliva for Streptococcus mutans for the two groups of volunteers, before and after 28 days of dental brushing with Titoil or a low abrasive dentifrice. 
from Group 2 are included in the statistical analysis of this study.

\section{DISCUSSION}

In Brazil, the population generally keep their teeth until an advanced age, when it is possible to see problems of increased sensitivity and root caries resulting from the use of abrasive dentifrices (cervical abrasion) $^{2,8}$. These lesions can be avoided by the substitution of abrasive dentifrices for an abrasive-free dentifrice containing vegetable oil ${ }^{3}$. At present, such a dentifrice is not available in the marketplace.

Salivary flow is very important to oral health ${ }^{6,15,18,20,23}$ and the almond oil contained in the dentifrice employed in this study maintained a salivary flow equal to that found when abrasive dentifrices are used (Graph 1). These findings contradict findings in other studies that indicated it was necessary to have abrasives in dentifrices in order to improve the salivary flow ${ }^{13,16,18}$.

The salivary buffer capacity is very important in the prevention of caries ${ }^{5,7,8}$ and differs between males and females ${ }^{20}$ due to hormonal differences. Only males participated in this research because they do not have hormonal variations as females do. This study shows that the vegetable oil is equal to regular dentifrice in terms of improving the salivary buffer capacity (Graph 3 ) and that it is not necessary to add abrasives to improve the buffer capacity of saliva, as shown in some studies $^{6,21,22}$.

\section{REFERENCES}

1. Aguiar AAA, Moimaz SAS. Redução da placa bacteriana dentária através da escovação com óleo de amêndoa [abstract]. Pesqui Odontol Bras 2000;14(Suppl):128.

2. Aguiar AAA, Moraes Filho FC. A interferência do óleo vegetal na aderência da placa bacteriana dental. Rev Cien Odontol 1998;1:21-4.

3. Aguiar AAA, Saliba NA, Consani S, Sinhoreti MAC. Óleo vegetal: um substituto aos abrasivos dos dentifrícios! [abstract]. Pesqui Odontol Bras 2002;16(Suppl):193.

4. Andrade Jr A, Andrade MRTC, Machado OWAS, Fisher RG. Abrasividade de dentifrícios: revisão de literatura. Rev Periodontia 1997;6:25-30.

5. Bueno MAM, Toledo S, Sallum EA, Nociti Jr FH. Influência da escovação dental orientada na redução do sangramento gengival, em áreas próximas a restaurações metálicas. Rev ABO Nac 1998;6(1):44-7.

6. Cury JA, Gil SS. Identificação dos pacientes com potencial cariogênico: avaliação preliminar do fluxo e da capacidade tampão salivar do brasileiro. RGO 1988;36(2):106-8.
Microbiological tests were used in this research because the international literature shows a relationship between $S$. mutans and caries ${ }^{12,18,19}$. This study demonstrates that when dental plaque is reduced, there is a decrease in the concentration of $S$. mutans microorganism ${ }^{11,15,17}$.This research also shows that the almond oil used in toothbrushing reduces dental plaque (Graph 2) more effectively than abrasive dentifrices and is equal in the reduction of S. mutans microorganisms (Graph 4).

We considered that it would be beneficial to expand this study to include different age groups and conditions of oral health in order to further demonstrate the advantages of removing abrasives from dentifrice.

\section{CONCLUSIONS}

After 28 days of habitual toothbrushing:

- Titoil and the low abrasive dentifrice performed equally to increase the salivary flow.

- Titoil had the capacity to reduce dental plaque bacteria and the low abrasive dentifrice did not.

- Titoil and the low abrasive dentifrice performed equally regarding the salivary buffer capacity.

- Titoil and the low abrasive dentifrice performed equally in significantly reducing the quantity of Streptococcus mutans in saliva.

7. Ericson D, Brathal D. Simplified method to estimate buffer capacity. Scand J Dent Res 1989;97:405-7.

8. Heath J, Wilson J. Abrasion of restorative materials by dentifrice. J Oral Rehabil 1976;3:121-38.

9. Krasse B. Risco de cárie: um guia prático para avaliação e controle. São Paulo: Quintessence; 1988.

10. Lara E, Panzeri H, Ogasawara MS, Ciampo JOD, Moraes JT. Avaliação laboratorial dos dentifrícios comerciais. Rev ABO Nac 1996;4:176-80.

11. Löe H, Theilade E, Jensen SB. Experimental gingivitis in man. J Periodontol 1965;36:177-87.

12. Löeshe WJ. Cárie dental: uma infecção tratável. Rio de Janeiro: Cultura Médica; 1993.

13. Luoma H, Luoma AR. Modification of the $\mathrm{pH}$ of human plaque by sucrose and bicarbonate-phosphate additives. Caries Res 1968;2:27-37.

14. Menaker L. Cáries dentárias: bases biológicas. Rio de Janeiro: Guanabara Koogan; 1984. 
15. Mendes MMSG, Zenóbio EG, Pereira OL. Agentes químicos para controle de placa bacteriana. Rev Periodontia 1995;jul/dez:253-6.

16. Moimaz SAS. Avaliação do efeito da profilaxia profissional e escovação habitual, nos índices de placa bacteriana de Turesky e O'Leary [Tese de Doutorado]. Araçatuba: Faculdade de Odontologia da UNESP; 1998.

17. Nelson Filho P, Baptistussi M, Azevedo RVP, Gugelmin MCMS, Ito IY. Prevalência de estreptococos do grupo mutans em saliva de escolares de 5 a 14 anos de idade, na cidade de Sertãozinho, SP. Rev Fac Odontol Bauru 1996;4(2):83-7.

18. Newbrum E. Cariologia. 2a ed. São Paulo: Santos; 1988.

19. Panzeri H, Pedrazzi V, Ogasawara MS, Ito IY, Lara EHG. Um dentifrício experimental contendo própolis: ava- liações físicas, microbiológicas e clínicas. Rev ABO Nac 1999;7:26-30.

20. Pinto VG. Saúde Bucal: Odontologia Preventiva e Social. São Paulo: Santos; 1989.

21. Silva ACB, Mira M, Pinudo SG, Vieira SR, Mezzadri S. $\mathrm{O}$ efeito do bicarbonato de sódio presente em dentifrícios sobre o pH salivar. DENS 1997;13:47-53.

22. Spadaro ACC, Caldeira TH, Rocha CB, Polizello ACM, Mestriner Jr W. Método para avaliação clínica da capacidade tamponante salivar. Rev Odontol Univ São Paulo 1998;12(3):247-51.

23. Thylstrup A, Fejerskov O. Cariologia clínica. $2^{\mathrm{a}}$ ed. São Paulo: Santos; 2001.

Received for publication on Feb 27, 2003

Sent for alterations on Nov 13, 2003

Accepted for publication on Apr 30, 2004 